It is concluded that intravenous diazepam therapy has a useful and important part to play in the treatment of severe convulsive status epilepticus.

We would like to acknowledge our indebtedness to Roche Products Limited for financial assistance and to Dr. John Garrod for his interest and helpful advice. We are grateful to Dr. Denis Harriman for the necropsy findings in Case 9 and to Dr. Kenneth Exley for help with the manuscript. We should also like to thank Mrs. Grace Murray for help in preparing the illustrations and Miss Hilary Stevens for typing the manuscript.

\section{REFERENCES}

Bamberger, Ph., and Matthes, A. (1966). Z. Kinderheilk., 95, 155. Boyer, P. A., jun. (1966). Dis. nerv. Syst., 27, 35. Eidelberg, E., Neer, H. M., and Miller, M. K. (1965). Neurology (Minneap.), 15, 223.

Femi-Pearse, D. (1966). Brit. med. f., 2, 862.
Gastaut, H., Naquet, R., Poiré, R., and Tassinari, C. A. (1965). Epilepsia (Amst.), 6, 167

Goldstein, N. (1963). Dia méd. urug., 29, 4492.

Gross, H., and Kaltenbäck, E. (1963). Helv. med. Acta, 30, 660.

Hernández-Peón, R., Rojas-Ramirez, J. A., O'Flaherty, J. J., and Muzzuchelli-O'Flaherty, A. L. (1964). Int. F. Neuropharmacol., 3, 405.

Iborra, J. E. (1965). Proceedings of 8th International Conference on Neurology, Vienna, vol. IV/1, 375 .

Lombroso, C. T. (1966). Neurology (Minneap.), 16, 629.

Morillo, A. (1962). Int. 3. Neuropharmacol., 1, 353.

Naquet, R., Soulayrol, R., Dolce, G., Tassinari, C. A., Broughton, R. and Loeb, H. (1965). Electroenceph. clin. Neurophysiol., 18, 427.

Payne, R. W., and Ishmael, W. K. (1963). W est. Med., 4, 40 .

Piqué, E. R., and Henking, R. (1965). Psychiat. et Neurol. (Basel), 150, 214.

Randall, L. O., et al. (1961). Curr. ther. Res., 3, 405

Revol, M., Courjon, J., Gerin, P., and Fischer, G. (1965). Rev. neurol., $113,266$.

Schallek, W., and Kuehn, A. (1965). Med. Pharmacol. exp. (Basel), 12

Zabransky, F., and Kuehn, A. (1964). Arch. int. Pharmacodyn., $149,467$.

Trolle, E. (1965). Acta neurol. scand., 41, Suppl. No. 13, 535

\title{
Intermittent Haemodialysis: Insertion and Care of the Silastic-Teflon Cannula
}

\author{
G. J. A. CLUNIE,* M.B., F.R.C.S., F.R.C.S.ED.; A. M. MARTIN, $\dagger$ M.B., M.R.C.P.ED. \\ B. NOLAN, $\ddagger$ M.B., F.R.C.S., F.R.C.S.ED.
}

Brit. med. F., 1967, 3, 88-90

The exteriorized Silastic-Teflon arteriovenous cannula introduced by Quinton, Dillard, Cole, and Scribner (1962) has simplified vessel access in patients requiring intermittent haemodialysis. Cannula complications still cause considerable discomfort and inconvenience to the patient, however, and account for much of the medical and surgical attention required. In the renal unit of the Royal Infirmary, Edinburgh, where this system of cannulation has been in regular use since October 1964, a number of modifications in the technique of insertion and aftercare of the cannulae have been made, and these are described in this report.

\section{Insertion}

All procedures were carried out in a surgical theatre. The nondominant arm was used wherever possible, the vessels cannulated being the radial artery close to the wrist and a forearm vein of adequate size. Leg cannulae were used primarily in three men whose work involved repetitive arm movements, and secondarily in one woman after loss of arm sites. The posterior tibial artery immediately proximal to the medial malleolus and the long saphenous vein at a slightly higher level provided satisfactory leg vessels (Fig. 1). Many patients requiring intermittent dialysis showed extensive atherosclerosis, and patency of and adequacy of flow through the ulnar or dorsalis pedis arteries were checked before ligation of the vessels used for cannulation.

The technique used was similar to that described by $\mathrm{Heg}$ strom, Quinton, Dillard, Cole, and Scribner (1961) and by Quinton et al. (1962). Both local and regional block anaesthesia proved satisfactory, but general anaesthesia was used in children or where multiple procedures were performed. Care was taken to avoid placing the subcutaneous loop over bone, since this

\footnotetext{
- Lecturer, Department of Surgical Science, University of Edinburgh, Edinburgh 8

† Registrar, Renal Unit, Royal Infirmary, Edinburgh 3,

₹ Consultant Surgeon, Royal Infirmary, Edinburgh 3.
}

caused early erosion of the overlying skin. Longitudinal incisions were used over the artery to allow adequate exposure, but the wounds were closed in at least two layers to bury the cannulae as deeply as possible. Transverse incisions were used for vein cannulation (Clark and Parsons, 1966), the security

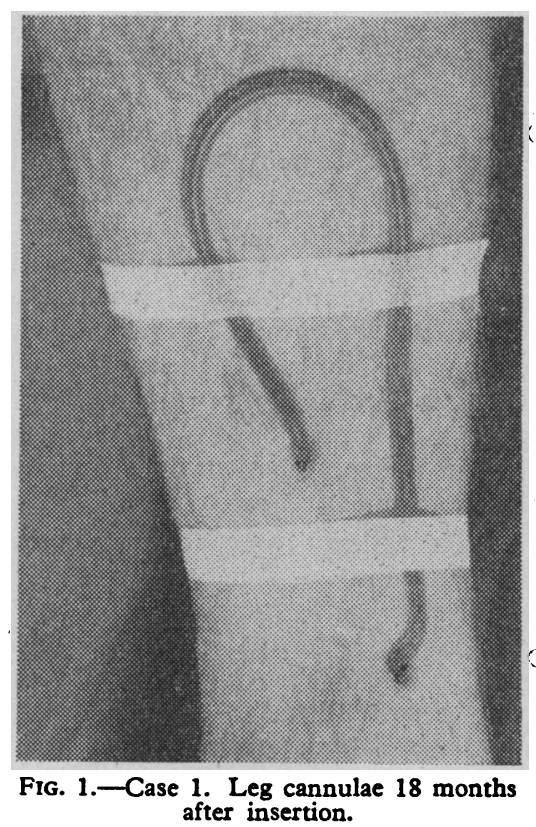

of closure and avoidance of later erosion through the wound compensating for lack of access in the more superficially placed vein. A single vertical incision proved satisfactory where artery and vein lay close together and at approximately the same level, and was particularly useful in the leg.

The Teflon tip used was the largest compatible with the original vessel diameter, and vein tips were always at least one 
size larger than arterial, in order to avoid pressure gradients in the shunt. Crimp and joint rings at the Silastic-Teflon junction were used initially (Fig. 2A), but as the internal rings tended to ulcerate they were replaced by extending the distal vessel ligature around the cannula. A single break shunt (Fig. 2B) with a long venous Silastic segment (Sevitt, Comty, Rottka, and Shaldon, 1964) was used, and the original Teflon-toTefion external bayonet junction was replaced by the insertion of a large vessel tip between the Silastic ends. The making and breaking of this junction was later made easier by discarding the external rings. No accidental leaks have occurred with this simplified system. External metal stabilizers caused skin reactions and were therefore replaced by Micropore Tape (Minnesota Mining and Manufacturing Company).

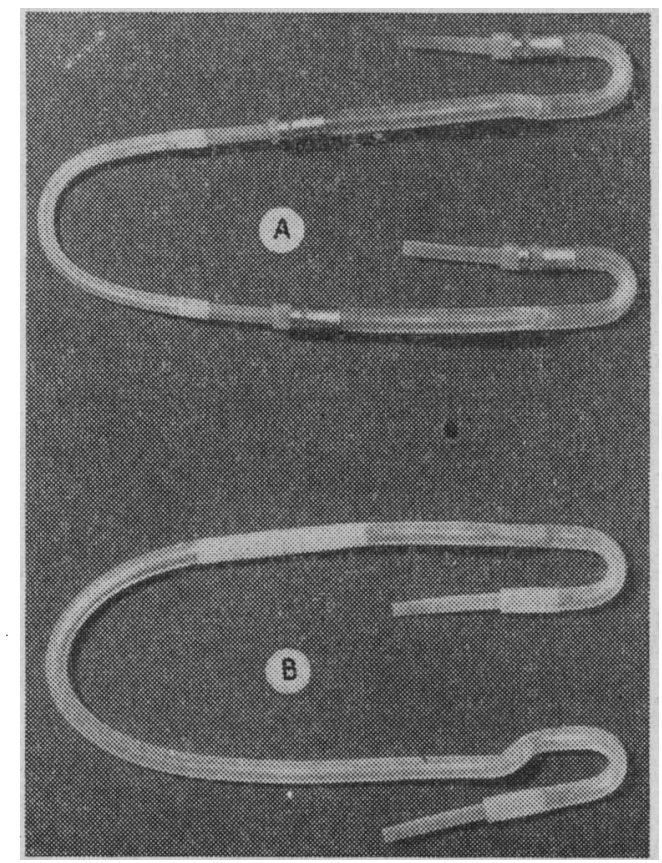

FIG. 2.-A, Original form of shunt with crimp and joint rings, short Silastic segments, and an external Teflon loop. B, Simplified form of shunt without rings, a long venous Silastic segment, and a single external Tefion break.

Movement of the cannulated limbs was reduced postoperatively by elevation in a sling for two days in the case of the upper limb, and by confinement to bed for 10 days in that of the lower limb. Splints were not used. Skin sutures were removed at two weeks. Wound healing was appreciably faster and more satisfactory when the patient's general condition was good, or had been improved by blood transfusion and peritoneal dialysis (Pendras and Smith, 1966). Use of the shunt was avoided within seven days of insertion so far as was possible, but earlier dialysis did not compromise the life of the cannulae.

\section{Aftercare}

The daily dressing and toilet described by Quinton et al. (1962) was not used, and, unless there was leakage between dialysis, the dressings were left undisturbed until the time of the next treatment. All patients showed skin reactions to cleansing agents used at the time of treatment, and a simple mechanical toilet with swabs soaked in normal saline was found to be more satisfactory. Bacteriological swabs were taken before and after each dialysis from the cannula exit wounds and the exposed ends of the external Teflon break. Light dressings and bandages were used to allow free use of the limb, the proximal end of the loop being loosely covered to allow frequent inspection by the patient for clotting.

\section{Results}

The cumulative experience in 11 patients over 12.1 patientyears between 1 October 1964 and 30 September 1966 is shown in the Table. Patients under treatment for less than three months and those who were treated for short periods before renal transplantation were not included in the series. Cannulae functioning on 30 September 1966 were thought to have failed on that day in order to estimate mean cannula survival times. The mean arterial cannula life was 7.6 months and the venous 7.3 months.

Experience in 11 Cases

\begin{tabular}{|c|c|c|c|c|c|c|c|c|}
\hline \multirow{2}{*}{$\begin{array}{l}\text { Case } \\
\text { No. }\end{array}$} & \multirow{2}{*}{ Age } & \multirow{2}{*}{ Sex } & \multicolumn{2}{|c|}{ Cannula Failures } & \multirow{2}{*}{$\begin{array}{l}\text { Treatment } \\
\text { Duration }\end{array}$} & \multirow{2}{*}{ Clotting } & \multirow{2}{*}{$\begin{array}{c}\text { Infee- } \\
\text { tion }\end{array}$} & \multirow{2}{*}{ Erosion } \\
\hline & & & Artery & Vein & & & & \\
\hline $\begin{array}{r}1 \\
* 2 \\
* 3 \\
* 4 \\
5 \\
* 6 \\
* 7 \\
8 \\
* 9 \\
* 10 \\
* 11\end{array}$ & $\begin{array}{l}25 \\
20 \\
34 \\
20 \\
33 \\
26 \\
34 \\
19 \\
39 \\
37 \\
27\end{array}$ & $\begin{array}{l}\mathbf{M} \\
\mathbf{M} \\
\mathbf{M} \\
\mathbf{F} \\
\mathbf{M} \\
\mathbf{F} \\
\mathbf{F} \\
\mathbf{F} \\
\mathbf{F} \\
\mathbf{M} \\
\mathbf{M}\end{array}$ & $\begin{array}{l}0 \\
0 \\
1 \\
2 \\
1 \\
1 \\
1 \\
2 \\
0 \\
0 \\
1 \\
0\end{array}$ & $\begin{array}{l}1 \\
1 \\
2 \\
2 \\
2 \\
1 \\
1 \\
0 \\
0 \\
0 \\
0\end{array}$ & 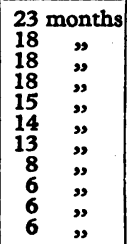 & $\begin{array}{r}4 \\
2 \\
10 \\
7 \\
12 \\
0 \\
8 \\
1 \\
0 \\
4 \\
0\end{array}$ & $\begin{array}{l}1 \\
1 \\
3 \\
5 \\
0 \\
3 \\
4 \\
0 \\
0 \\
2 \\
1\end{array}$ & $\begin{array}{l}0 \\
0 \\
0 \\
0 \\
0 \\
3 \\
2 \\
0 \\
0 \\
1 \\
0\end{array}$ \\
\hline
\end{tabular}

The two main limiting factors were clotting and infection. Forty-eight episodes of clotting occurred in 8 of the 11 patients, leading to loss of cannulae on 10 occasions. One of these cannulae also showed evidence of infection. In the majority of patients episodes of clotting were due either to an external cause such as kinking or compression of the shunt or to exposure to cold, as in a man with leg cannulae who stood in a river for four hours while fishing. Episodes of spontaneous clotting occurred fairly often in a smaller group of patients, and appeared to be due either to hypovolaemia secondary to serum protein deficiency or to a phlebitis of obscure origin. Declotting was easily carried out with the methods described by Hegstrom et al. (1961) and by Pendras and Smith (1966) if the patient reported within three hours of the episode, particularly if there

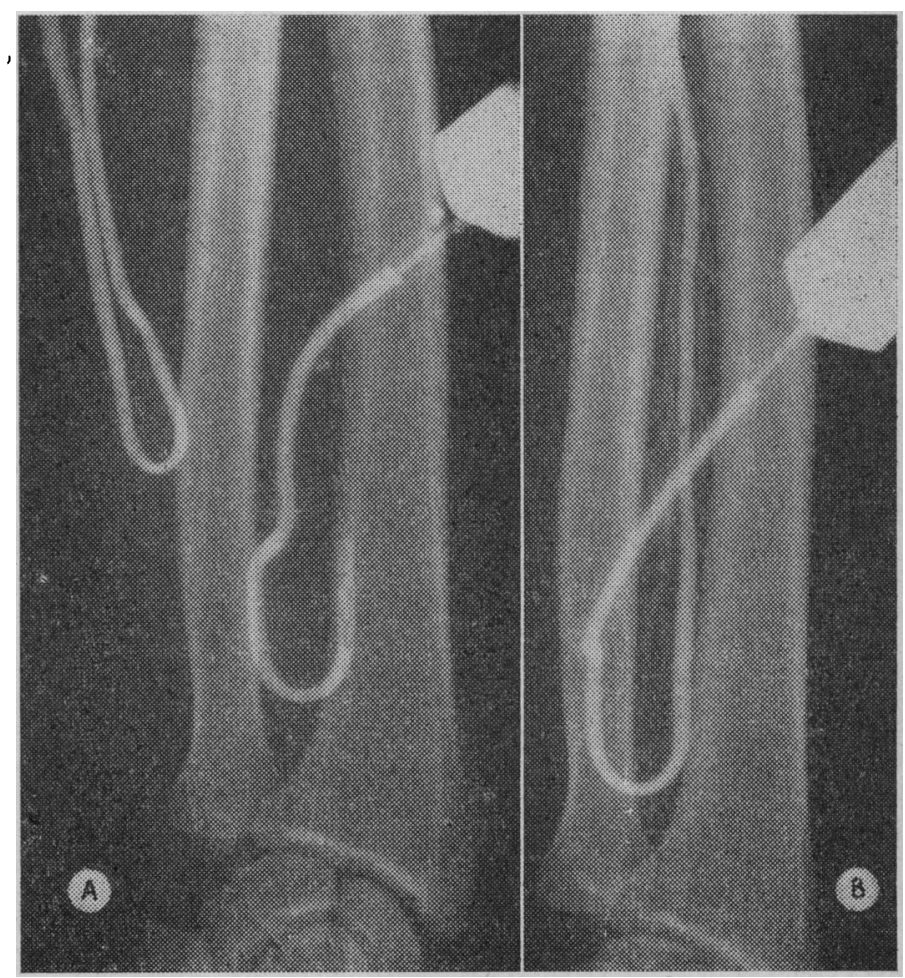

Fig. 3.-A, Arteriogram performed after routine declotting procedures. This cannula has been clotted for 24 hours. B, Further arteriogram after streptokinase infusion: the small clot at the vessel tip was easily dislodged by suction. and flow restored. 
was an obvious mechanical cause. If flow was still unsatisfactory after attempted declotting, clots were occasionally dislodged or vessel spasm was overcome by the slow infusion of a solution of 20,000 international units of heparin in $500 \mathrm{ml}$. of saline. Angiograms were performed by the injection of 3 to $4 \mathrm{ml}$. of $60 \%$ Urografin via the open end of the cannula (Fig. 3) in resistant cases. An attempt was then made to dissolve visualized clot by the injection of 250,000 units of streptokinase (Kabikinase) in $2 \mathrm{ml}$. of sterile water into the cannula, which was clamped for 30 minutes. Flow was restored by this procedure on four of the seven occasions on which it was used. Where declotting was not successful, one limb or occasionally both limbs of the shunt were replaced. Anticoagulants were used systemically after recurrent episodes of clotting, and were particularly valuable where there was evidence of phlebitis.

Twenty episodes of infection occurred in 8 of the 11 patients, being secondary to skin erosion over the venous loop on seven occasions. Nine of these infections led to loss of cannulae. The causative organism was Staphylococcus atreus, except in twwo cases where a $\beta$-haemolytic streptococcus was isolated. Septicaemia secondary to cannula infection occurred in two patients, and was successfully treated by antibiotics without loss of the cannulae. Nasal, throat, and perineal swabs were taken before insertion of cannulae and at intervals thereafter. Attempts were made to eradicate nasal and skin carriage of staphylococcus, but persistent carriers were treated with lincomycin (Lincocin), cloxacillin (Orbenin), or methicillin (Celbenin) from the time of insertion of cannulae for periods of two to four weeks. If infection became established and persisted in spite of antibiotic therapy, the cannulae were removed and another limb was cannulated next day under antibiotic cover. In four patients with infected arterial cannula wounds persistent bleeding occurred, and was found to be due to false aneurysm formation. Bleeding was controlled by proximal ligation of the vessel and removal of the cannula. A more detailed analysis of these infections, with particular refer- ence to phage typing and the source of the organisms, will be presented elsewhere.

\section{Summary}

Two years' experience with the Silastic-Teflon arteriovenous cannula system in the management of patients with chronic renal failure by intermittent haemodialysis is reported. The mean arterial cannula survival time was 7.6 months and the venous survival time 7.3 months. Careful attention to a number of apparently minor points during insertion improved cannula survival. The two limiting factors in cannula life were clotting and infection. Declotting was usually achieved if the patient attended within three hours. If flow was unsatisfactory after using standard declotting procedures angiography was performed and streptokinase infused into the cannula. Flow was restored in four out of seven cannulae by this method. The causative organism was Staphylococcus aureus in almost all the cases of infection. Antibiotics were used both prophylactically and therapeutically, but cannula removal and replacement in another limb was necessary in 9 out of 20 cases of infection.

We wish to thank Dr. J. S. Robson and Professor M. F. A. Woodruff for permission to report on cases under their care, and for their advice and encouragement; Dr. R. W. Tonkin for the bacteriological investigations; Dr. D. J. Sinclair and Dr. T. A. S. Buist for the angiographic studies; and Mr. A. Patterson for the photographs.

\section{REPERENCES}

Clark, P. B., and Parsons, F. M. (1966). Brit. med. F. 1, 1200 Hegstrom, R. M. Quinton, W. E., Dillard, D. H., Cole, J. J., and Scribner, B. H. (1961). Trans. Amer. Soc. artif., intern. Organs, 7, 47.

Pendras, J. P., and Smith, M. P. (1966). Ibid., 12, 222.

Quinton, W. E., Dillard, D. H., Cole, J. J., and Scribner, B. H. (1962).

Ibid., 8 , 236 . C., Rottka, H., and Shaldon, S. (1964). Proceeding of the European Dialysis and Transplant Association, 1, 271.

\title{
Prevention of Urinary Infection by Means of Closed Drainage into a Sterile Plastic Bag
}

\author{
W. A. GILLESPIE,* M.D., F.C.PATH., F.R.C.P.I., M.R.C.P. ; G. G. LENNON, † M.B., CH.M., F.R.C.O.G., M.M.S.A. \\ K. B. LINTON,ł PH.D., B.SC.; G. AUDREY PHIPPEN,§ S.R.N.
}

Brit. med. F., 1967, 3, 90-92

If urinary infection is to be avoided when indwelling catheters are used, bacteria must be prevented from entering the bladder or destroyed soon after they enter. Infection through the catheter may be prevented by drainage into a closed sterile container. Passage of bacteria between catheter and urethral wall (an important route of infection in females) may be diminished by immobilizing the indwelling catheter. Application of these measures, together with disinfection of the urethra and bladder when catheters were inserted, reduced the postoperative urinary infection rate in gynaecological patients from 97 to $13 \%$ (Gillespie, Lennon, Linton, and Slade, 1962, 1964).

Drainage bottles containing formalin, which were used in these studies, were troublesome to prepare. We report here the

- Professor of Clinical Bacteriology, University of Bristol. ' + Professor of Obstetrics and Gynaecology, University of Bristol. — Lecturer in Medical Bacteriology, University of Bristol.

Ward Sister, United Bristol Hospitals.

Supplied by Eschmann Bros. and Walsh Ltd., Shoreham-by-Sea, Sussez. results obtained with the use of closed sterile plastic bags instead of bottles.

\section{Materials and Methods}

Meredith|| urine drainage bags were used after 1 January 1965 (see Photograph). The drainage tube, which is sealed into the bag, ends in a valve, a flat collapsible plastic tube. Any increase of pressure in the bag closes the valve and prevents reflux of urine into the tube.

The patients, all of whom had uninfected urine initially, underwent gynaecological operations similar to those in the previous investigation and were treated in the same ward. Their bladders were drained by indwelling Foley catheters for four days after operation; during the next few days most patients were catheterized intermittently, between one and six times in all, to remove residual urine. Except for the substitution of 